\title{
Are Female Clowns Politically InCorrect? A Case Study on Female Clowns' Political Engagement at THE 7TH “EsSe Monte De MulHeR PALHAÇA" FESTIVAL IN RIO DE JANEIRO
}

\author{
Delphine Cézard ${ }^{1}$ \\ Independent researcher, Montréal, Canada
}

\begin{abstract}
By linking the notion of politics with clown practices played out during the biennial festival «Esse Monte de Mulher Palhaça» in Rio de Janeiro (2018), dedicated specifically to female clowns, the relations between politics and feminism are raised, as well as the question of the place of clowns and women within the social system in which they act. In addition to reassessing the concept of politics through this new field of application, looking at what artistic practices convey or denounce as inequalities, allows us to identify politicized and political social elements. The private sphere, the power relations, the importance of gender, and the body and sexuality as treated in the festival's performances raise political issues. We are lead to think of the phenomenon of Brazilian female clowns as a political space of claims, in particular feminist ones, and a resistance to dominant sexist normativity.
\end{abstract}

Keywords: female clowns, politics, feminism; activism, Brazil

\footnotetext{
All profound truths take on political meaning, that meaning is conferred not through the speaker, however; it is the situation itself, it is the social and historical reality, founded in power, that makes all realist discourse immediately political.
}

Bertaux (1977: 294)

Esse Monte de Mulher Palhaça is a biannual clowning festival held in Rio de Janeiro, dedicated specifically to female clowns. The 7th edition, held in late summer, 2018, had the dubious honor of taking place during the first round of presidential elections between the far-right party of Jair Bolsonaro and the "Workers' Party" (PT) of Fernando Haddad. On the festival grounds, as well as in the city, it was hard to step outside of this socio-political context. The political context of Brazil cannot entirely explain the political nature of the festival, however.

1 Doctorate in Arts and Science, Circus Artist. Author's contact: delphine.cezard@gmail.com 
The evident question then is, what would a clowne ${ }^{2}$ festival have to do with the politics of the country, or with politics at all?

We must ask ourselves if the festival and the participating clownes have entered the political arena, and if so, to what extent and why. Through the nature of their art form, clowns are characterized as irreverent, maladroit and almost always being on the losing side of things. It seems essential to question the form and degree of irreverence with which clownes at the festival interacted with politics. The question extends to the world ${ }^{3}$ of clown and its relationship to societies in general. The objective of this article is to examine the political dimension of the artistic practice of clowning by studying the festival's artistic performances, the presence of those performances in the public space, and the Brazilian and South-American community of clownes at Esse Monte de Mulher Palhaça.

Observing the socio-political dimension of the world of clownes will, as Bernard Lahire suggests, "reveal the social nature of what is being studied and, in this case, show that individual realities are social, and that they are socially produced" Lahire (2004: 17). In this particular case, we will establish how the subject of personal intimacy relates to the artistic activity of clowning and how the latter is impacted by a country's politics, which may be defined as a territory as well as a geo-political space. Politics, in its origins, is the activity by which society organizes its "city" or society. It can be carried out through or appear as art, the economy, or even as religion. In cultural geography, the notion of territory itself is understood as the identities and cultural dimensions of a particular space. This article will make use of this understanding of the notion of territory within each of its possible dimensions, namely a "geo-political territory," a "collective territory," and the "individual territory."

Cultural and artistic practices often convey a number of struggles and inequalities that, because of their lack of visibility, are highly political. The aim of this study is to highlight the connections between these themes and in particular the connection between politics and society created through the performance of clowning. We will also answer how clownes take ownership of their political role and explore the more silent aspects of their existence, their organization, and their place in society.

The survey was conducted in Rio, Brazil, from August 25, 2018 to September $5^{\text {th }}, 2018$. The ethno-sociological methodology used was similar to empirical research where ethnographic observational techniques are applied to sociological issues. Deployed, in effect, as an ethnology of the arts, this study considers the body as the first instrument both in the measuring of man and in contributing to the sociological knowledge of the object of study, Leveratto (2000). This methodology led to a number of observations through moderate participation in the greatest number of workshops as was possible, and through active participation, notably in the open debates and conferences.

Finally, with a perspective inspired by ethnomethodology, the discussions and conversations heard or held during the study, constituted an object of particular attention. According

2 In this article, given that a gendered word for "clown" does not exist, the French word "clowne" or "clownes" will be used to denote female clowns. The gendered French word "clowne" falls short, however, of any proposed oral change leaving women still subject to invisibility.

3 The notion of world, as used here, refers to the collective dimension and collective organization of the creation and diffusion of an art (Becker, 1988). 
to Harold Garfinkel, ethnomethodology "seek[s] to treat practical activities, practical circumstances, and practical sociological reasoning as topics of empirical study, and by paying to the most commonplace activities of daily life the attention usually accorded extraordinary events, seek[s] to learn about them as phenomena in their own right." Garfinkel (2007: 1) Most often held spontaneously, informal conversations escape the control of organized thought and facilitate the observational penetration of the investigated world's modus (habitus) and salient events. The study, therefore, is supported by observations made outside of the proposed workshops and shows, as well as by conversations and unrestricted meetings at the participants' hostel, in the homes of the people who hosted me, or with those with whom I interacted afterwards (approximately twenty people in total).

First, we need to look at how politics and feminism articulate themselves within the practice of clowning. The culture and cultural institutions of a nation have an impact on artistic professions, and subsequently, on the lives and living conditions of artists, in this case of clown.e.s. The political context of Brazil in particular has not fostered a uniform development and support of the clowning world, pushing it to become more autonomous. This has also been the case in Europe, Cézard (2014), where the first women to integrate the field, such as Annie Fratellini, had to hide their gender and their passion for clowning in order to practice the profession. In the minority, and viewed poorly within the practice of clowning for many years, clownes are now numerous in both Europe and Brazil (in fact, many are beginning to gain notoriety in France, such as Daphné Clouzeau, Gardi Hutter, Charlotte Saliou, Elsa Foucade, Diane Bonnot, Catherine Germain, Sabrina Maillé, etc). The new status of women in the profession raises questions about the social and artistic conditions giving rise to this unprecedented progress and the links that might be made to feminism.

Said another way, we will observe how the territory of politics acts on the organization, practice, and ideology of clownes. Subsequently, barriers imposed by political and social systems will be evaluated in order to understand the methods used by clownes to upend them. If a festival of female clowns, by its very existence, has a de facto political activism, then surely the systems around it have been built on the basis of powerful and implicit social norms grounded in heteronormativity, monogamy and phallocracy. Therefore, it seems difficult, if not impossible, for the clownes to create innovative or provocative artistic proposals that are not related to those systems. The dual nature of the clownes relationship with these systems' authoritative social norms, at times constraining and oppositional, and at times facilitating and collaborative, will be studied.

As with feminists, clownes adapt their activism to the society they face, and opt for new solutions based on their diversity and the intersectional nature of their struggles. We will see then the impact of territory in its social dimension on feminist practice in this context, as well as the impact of clownes'collective actions and community on the notion of territory in return.

Finally, we will observe why and how women use the art of clowning to fight certain battles. The importance of gender, body, sexuality, the private domain, and power relations as they appeared within the festival's performances will be considered, as well as how those performances asserted these themes as political issues. It will be necessary to understand how the intersection between political and personal spheres can form the basis of political activism. Language surrounding the practice of clowning will also be studied through the prism of politics, both in terms of directly politicized statements and the uses and social modalities of 
language. To translate what these mean for the territory itself, we will need to consider individuals as the smallest political territories within the geographic space and see how individuals are assigned membership within the collective territory of "clown."

Our aim will be to demonstrate that the phenomenon of Brazilian clownes can be concieved as a stage for political activity, especially feminist activity, and as a resistance to the dominance of sexist gender normativity.

\section{CLOWNES: A DE FACTO POLITICAL AND FEMINIST STATUS}

At first glance, clownes relate to politics only sporadically, whether through cultural institutions or otherwise, by comic device. Their socio-professional reality arises, however, directly from the polity and society within which they develop. Their existence as a part of that society and their implied social position, result directly from the system in place. Given this importance, the polity may act intermittently as a facilitator and an obstacle, at times enabling clownes to seize artistic or social opportunities, and later to become the subject of their political advocacy or resistance. Finally, in their relation to politics, there can be no doubt that clownes, as they exist within a social system, are confronted not only with the challenges of clowning as an artistic discipline, but also with challenges relative to their place in society as women.

To begin with we need to study the present political context in order to measure the reasons for clownes' continued presence within the Brazilian landscape. Then, the notion of feminism will be linked to the festival and to its conditions of existence.

\section{Cultural policy and conditions that favor the emergence and work of clownes}

An increase in the number of clownes, in some measure, requires the polity's support and recognition of the profession in its nature. A sense of activism and protest against a discriminatory and oppressive system is necessary for an artist to work as a clowne. Thus the art of clowning views its conformity to the system with ambivalence: it needs a certain level of conformity to survive, but must also disobey or contradict it by the very nature and identity of its work.

Brazil's cultural policies have over the last half century, attempted to help artistic projects flourish. Notable efforts have been made, including the creation of the $\mathrm{SESC}^{4}$ and the strengthening of the welfare state in the 1970's. The policies of President Lula ${ }^{5}$, which created the Secretariat for Diversity and Cultural Identity ${ }^{6}$ in 2003, addressed a wide range of goals, including the institution of greater social protection, the democratization of access to social support mechanisms, the promotion of cultural exchanges among the different regions of Brazil

\footnotetext{
4 Serviço Social do Comércio.

$5 \quad$ President of the Republic of Brazil from 2003 to 2011.

6 Google books, link to the book " Mémoire et nouveaux patrimoines “, published by Vera Dodebei under the direction of Cécile Tardy, <https://books.google.it/books?id=KIMXCwAAQBAJ\&pg=PA80\&lpg=PA80\&d$\mathrm{q}=1 \mathrm{ula}+\mathrm{acc} \% \mathrm{C} 3 \% \mathrm{~A} 8 \mathrm{~s}+\% \mathrm{C} 3 \% \mathrm{~A} 0+$ culture\&source=bl\&ots=4cLEIVp3n3\&sig=ACfU3U0R9kWcAy6JfkVQLsniNvWv_i5TEg\&hl=en\&sa=X\&ved=2ahUKEwjSqab14J3hAhVDMewKHe0KCHkQ6AEwBXoECAgQAQAQ\#v=onepage\&q=lula\%20acc\%C3\%A8s\%20\%C3\%A0\%201a\%20culture\&f=false>, accessed 29 March 2019.
} 
and among their cultural groups, and the creation of greater awareness of the characteristics of gender, sexual orientation, age, and popular culture. Additionally, in 1991, Parliament passed the Rouanet Act designed by diplomat, academic, and Secretary of State for Culture, Sergio Paulo Rouanet. ${ }^{7}$ The act allows individuals and companies to deduct the amount invested in a Ministry approved cultural project from taxes on their revenue or profits. ${ }^{8}$ Thus a dual system of cultural financing, both private and public, was established. For example, in 2015, the Ministry of Culture's budget was raised to $\mathrm{R} \$ 2.6$ billion, while the funds collected through the Rouanet Act totalled $\mathrm{R} \$ 1.18$ billion. ${ }^{9}$ It is in this dual context, and particularly after the country's re-democratization in the 1980's, Lima Campos (2017: 37), that clownes have attempted to find funding and support.

As in Europe, this mechanism of financial support, when directed towards an artistic world viewed by many with little legitimacy, has pushed the clownes to invest in their own milieu. Since the 1980's the clownes have built, with their own limited and non-guaranteed resources, an independent network for diffusion, training and support, Cézard (2014). Today, the massive development of festivals dedicated to clownes in Brazil - around ten in a few years - is an indicator not only of how women may hold the floor through the art of clowning, but also of the autonomy ${ }^{10}$ they give themselves. Indeed, for clownes, the creation of a festival corresponds to the creation of performance opportunities, enabling the diffusion of their message, allowing them to live from their art, and creating a form of collegiality that opens a space for safe exchange among peers.

Moreover, for a clowne, managing the production of a festival, can increase her overall income when finances from touring are not sufficient, or when self-promotion is too costly in terms of time. Several years ago, Giovanna Parra attended the Esse Monte de Mulher Palhaça festival as a spectator. This year, she returned as a clowne. In the meantime, she has started organizing a similar festival - Encontro de Mulheres Palhaças de Uberlândia - in her home state of Minas Gerais. For her, creating her own festival and participating in those of her peers have been faster and more reliable than the marketing and management of her tours as a clowne. During her workshop "The best story is the one we tell about ourselves," Fran Marinho explained that she talks a lot about production, because it is one of the essential challenges of a clowning career. Darina Robles Pérez, a Mexican clowne with twenty years of experience, has recently founded her own clowne festival in Mexico, with the support of Manuela Matusquella, clowne and producer of the clowne festival in the Brasilia region. Becoming autonomous in their occupation - from production to performance - has been essential for their survival.

These socio-political conditions of artistic survival delineate certain choices for clownes, in particular the types of training and education offered to them. The number of training courses, their quality and duration depend on political choices, support from the government, and private funding. Limited resources push clownes to prefer short-term training, learning

\footnotetext{
7 "Le Monde", article on private financing of culture in Brazil, <https://www.lemonde.fr/culture/article/2016/06/30/bresil-le-financement-prive-de-la-culture-en-cause_4960909_3246.html>, accessed 29 December 2018.

8 "La France et le Brésil, terres de cultures", French Senado Federal website, <http://www.senat.fr/rap/r09646/r09-6461.html>, accessed December 31, 2019.

9 Op. Cit. "Le Monde."

10 The notion of "autonomy" refers to the fact that a world is built around a functioning that is unique to it and that makes it relatively independent of external logic.
} 
on the job, and, for the most fortunate, international education. This this last option especially requires financial means. In an informal interview, a clowne pointed out that she had given up her acceptance to the École Jacques Lecoq, because the training would have cost her as much as buying a car in Brazil.

Regarding these socio-political conditions, the recently instated provisional measure $\mathrm{n}^{\circ} 870 / 2019^{11}$ reduced the number of ministries within the federal government of Brazil from 29 to 22, with the result of eliminating the Ministry of Culture. Furthermore, the current mandate of the federal government no longer considers arts and culture as part of the strategic development plan for the country. These latest measures allow little hope for the growth of clowns or for the development of their work conditions.

Despite these latest developments, the political context of Brazil over the past fifty years has made it possible to bring about real changes in the lives of the artists. These changes occasioned a tangible development and an unprecedented amplification of the clownes' voice and community. How did the clownes shoulder and take ownership of the art of clowning? Is there a link between feminism and the fact that the clowning world is becoming more feminine?

\section{Which feminism?}

The massive presence of women in the clowning field is not just due to the cultural policy of the state. Women's integration into the clowning milieu should be considered and translated in political terms with regards to feminism, defined to begin with in its broadest accepted meaning.

The network of mutual support among clownes, which forms the foundation of the festivals' development, represents an ideal means of financing (as producers) and performance (as clownes). With this, it is not difficult to view this network as an illustration of "sorority," as advocated for by the American feminist movements in the 1970s: a "relationship of similarity, or solidarity that unites women as equals in sharing the feminine condition." 12 The festivals foster and unite clownes through their vocation, permitting their profession's stabilization and providing tools for its viability. Certainly the creation of a network is essential to the diffusion of an art form and, by extension, to its recognition, Cézard (2014). Besides offering visibility and legitimacy at an institutional level to clowning as an artform, the festivals offer the same to the women who practice it. By promoting such a platform, the dimensions and definition of a woman's image and place within clowning and in society at large are redefined.

In fact, the festival's exclusive posture in favor of women and clownes can be compared to the notion of feminism, understood in its broadest sense "[...] as the whole of discourse that denounces the conditions imposed on women in patriarchal society and that seeks the means

11 "Federal Senate", website of the Official Senate, <https://www12.senado.leg.br/noticias/materias/2019/01/02/medida-provisoria-confirma-estrutura-de-governo-de-jair-bolsonaro>, accessed January $3^{\text {rd }}$ 2019.

12 “CNRTL, Centre National de Ressources Textuelles et Lexicales", CNRTL website, <http://www.cnrtl.fr/ definition/sororit\%C3\%A9>, accessed December 312019. 
to transform these conditions" Lamoureux, St-Gelais (2014: 8). For example, Ana Borgès ${ }^{13}$ explained how the Esse Monte de Mulher Palhaça festival has allowed clownes to improve as performers not only by providing an appropriate platform for diffusion and an audience to confront, but also by providing opportunities to transform clowning duos that include men. Indeed, men have sometimes not been permitted to perform at the festival, even as a part of a duo with a woman, because of an unequal weight in the importance of roles within the duo. By scrutinizing the representation of gender within duo acts, the festival has enabled some clownes to create richer performance material, either within their duets or in new solo work, without reifying the traditional status of women in clowning, or in other words, without relegating themselves to a minor or supporting role compared to a masculine character or men. Subsequently, the clownes were able to reintegrate their duo while in a position of strength and eventually allow their male partners to join the festival, ${ }^{14}$ which constitutes a significant, if not to say unprecedented, inversion of the usual roles and the usual story.

In a similar way, this sorority found expression during the 7th edition of the festival by creating a network of university researchers specialized in clowning. ${ }^{15}$ The collegiality thus created could generate joint publications. Each year since its creation, in fact, the festival has chosen to intentionally develop a distinct aspect of the community that would bring increased legitimacy to the festival and to the work at large. For example, focuses have included giving more visibility to clownes, obtaining greater financing for production - as was the case during the second edition - expanding the clowne network across different regions of Brazil, or initiating the collective conception of a publication. These efforts exemplify how "the present feminist wave helps us to gather strength and forces to continue transforming" Miranda (2017:11). The mantle of the term "feminist" can be difficult for both those who grant themselves the title and for those given that designation by their milieu (on the one hand, a possible reproach for the term's misuse and on the other, the difficulty of embodying that title in the context of male domination). However, the discussion, denouncement and abolition of the war of the sexes, are feminist acts, whether these be through the proposed inversion of the traditional roles of winner and loser; the underlining of the complexity in gender relations and the weight given gender by society; or the denouncement of the conceptual "normal" body type, Bérard, Zanin (2014: 154). The festival, through its implication in a phallocratic society and its choice to offer exclusivity to women, is by default feminist.

First, it appears that through its chosen dedication to female clowning, the festival finds itself, voluntarily or not, at the heart of politics and gender issues; and further, that feminism and politics are indivisible.

While the clownes have long lacked visibility, Brazilian clownes have organized themselves to create training and performance spaces despite the political and financial difficulties presented by their national context. A network of underground and, in its widest sense, feminist support has been put into place by clownes allowing them to pool resources, access work, and share greater autonomy. Returning to the notion of territory, it appears that political territory impacts artistic practice, and that in response the solidification of a clowne community has

13 These comments were exchanged during an informal interview. This is the case with all the clownes' statements cited in this article.

14 The male clowns who performed at the festival were included in the program due to family shows, performed with spouses/partners and children.

15 It happened that all the researchers attending were clownes, except the author. 
allowed the artform to find its place. Beyond that contextual political posture, we have to ask if, as a part of their performances, the clownes take on any more directed feminist, or political postures. Equally, the limits and reach of the festival's political activism must be questioned. Can a festival change social norms? How far can its involvement go and through what means?

\section{FEMINIST STATEMENTS, LIMITS AND POSSIBILITIES}

The theme of the festival and content of the clowne's performances are purposeful, and the choices clownes must make in order to address their audiences from a feminist stance merit careful observation. Truly effective methods and arguments for pulling social norms from the system are difficult to find. First we must look at the system to which we are referring, and second, we must study the different means developed by clownes to counter, or even hijack, the normative practices within that system.

\section{Exiting a system that is intended to be hermetic}

The feminist posture of the festival stands in a socio-political space that needs definition in order for us to understand how clownes confront, or even upend it. We find two distinct feminist postures through which clownes provoked normativity in the observed performances. Before exploring how these two postures operate within the festival, we must look at the context in which they have evolved.

To set the stage, it helps to consider society as a political space that necessitates the production of stereotypes, maintains structural patterns, conveys ideological traditions, and carries habitual ways of thinking. These functions are based on class conflict and a patriarchal system that is phallocratic, monogamous and heterosexual. As Monique Wittig reminds us in her essay on "The Straight Mind," "heterosexuality is no longer considered only as a sexuality but as a political regime" Wittig (2013: 18). This social system, based on power relations and domination, generates discrimination and injustice toward women. Those injustices were denounced during the festival's conference, where almost every woman present took the floor to address subjects such as motherhood, loneliness, and homosexuality, as well as to define the difficulties they found within these domains as women. It is important therefore to note "how creative and communicative processes that promote the expression of individual and collective wounds, especially among groups that have experienced situations of violence, marginalization and exclusion, can promote not only a measure of healing, but also a socio-political affirmation that challenges the culture of power" Lamoureux, St-Gelais (2014: 4).

Today's societies exist under the political regime of class struggle and monogamous heterosexuality. Escape from this regime is not easy because it is not always apparent or circumnavigable. Norms implicit in an entirely androcentric system, internalized during the socialization of any person, are not only invisible by nature, but also difficult to redirect or destroy, since they develop in their own context and without counter example. To change the profound and often identity-based alienation produced by this system, intervention must operate at levels and degrees of society's structure. 
The strategic options for any feminist thought are also restrained, since they cannot advocate total systemic change and must therefore take the field either in the direction of re-appropriation or of proposition/replacement. The first strategy uses parody to re-appropriate the tools and frameworks proposed by the system itself; in other words "[...] the classic feminist strategy of subversive imitation (Butler 1990), a strategy of 'as if' (Braidotti 1994), or mimicry (Irigaray 1977) which consists of imitating the feminine norm in order to redirect its meaning" Bérard, Zanin (2014: 214). Clownes provide a number of examples. Julieta Hernandez in her act entitled Mais $^{16}$ performs an overtly botched and off beat strip-tease. Giovana Parra in $O$ vestido ${ }^{17}$ tries in vain, and not without difficulty, to put on her wedding dress.

The second strategy is that of complete departure from the norm. For example, Carolina Duncan Page in Primeiro encontro offers a character and a story that are agendered. While Diani Brum's $O$ casamento o a união ${ }^{18}$ concludes with her proposing marriage to a girl, leaving a previous male fiance in the arms of another. Still other clownes, by presenting their take on standard or classic clowning acts, i.e. acts produced in "normal" times by men, allow themselves to rewrite the classics by feminizing them, thus proving that virtuosity is also feminine. Such is the case with the act Ub! Que Lelas ${ }^{19}$ by the Cuerpa Circa collective; Camila Bastera, Camila Mirkin, and Maria Scacchi, who revisit the art of the musical clown trio. Lily Curcio's show Travessias $^{20}$ also includes a series of classical clowning references such as the use of a tiny violin, ballet, long shoes and wide clothing, the personification of a travelling companion through an object, and allusions to traditional Russian and European clowns. In general with this strategy, it remains difficult to step outside of the system, to abolish it, because it is through that system that societies are educated. This leads Monique Wittig to say that "feminism rests currently on a reform of the system rather than a desire to abolish it" Wittig (2013:21). It would be impossible for clownes, for women, or for any oppressed minority struggling for visibility, to suddenly reform an entire system, or to destroy in one fell swoop the categories of class and gender that serve as the system's foundation. At most, clownes can hope - through laughter - to upend certain representations, Lamoureux, St-Gelais (2014: 84) representations created of, and by, the oft-named system.

Difficult as it may be to subvert the system, to the current generation of clowns it presents an object to be questioned and provoked. They find within the language of clowning, tools to underline injustices and to invert meanings. What tools for advocacy have been put to use? What injustices have been made visible and by what means?

\section{Plurality and intersectionality as foundation and subject of the struggle of equality}

The Festival's clownes created their artistic statements in reflection of both who they are, and of the intersectional struggles they encounter. It is necessary to study the social realities and norms they have chosen to battle against or, simply put, to make fun of.

\footnotetext{
16 "More"

17 "The dress"

18 "The marriage or union"

19 The title is an exclamation having no strict meaning.

20 "Crossway"
} 
Feminism redirects its forces over time in the hope of aiming true on a shifting front. If feminist struggles have hit a number of internal criticisms, it is because awareness within feminism itself has continuously grown to match the discrimination present throughout the system, encompasing issues and fields of action long ignored, such as the question of race. The concept of "transversality," within Afro-feminism, arrives via Kimberlé Crenshaw in 1991, and changes the norms of feminism, opening its doors beyond what until then had remained a white threshold. In the United States in the 1980's, Amandine Gay wrote that Bell Hooks had already underlined the issue, explaining that Afro-feminism gave rise to "a refusal to separate [feminist] struggles and an affirmation of the singularity of black women, who belonged both to the world of black ethnicity and the world of women" (Hooks 2015). She argues that, in France particularly, there is a refusal to see white and black women "outside of a universalist rhetoric that makes the differences of color and associated hierarchies invisible," necessitating a new awareness of their place today within power relations in society. Of equal importance, then, is the fight against the politicization of feminist struggles and the "responsibility for eliminating all the forces that divide women" Hooks (2015: 388). Angela Figueiredo explains that black women had been so invisible within the feminist struggle that "[...] there was a tension surrounding the definition and self-definition of black women who, for the most part, refused to be defined as black feminists" Figueiredo (2018: 1090). It was necessary then that white feminism open itself to the complexity of other struggles, that is to say, to become intersectional and consider the diversity of realities that englobe the notion of "women" while always making an effort to "carefully dissociate 'women' (the class from within which we fight) and 'woman,' the myth" Wittig (2013: 52). What better way to express this diversity and inclusivity than through the art of clowning, with its pluralistic and varied forms? Castro (2005: 206).

During the festival, the female clownes on stage portrayed lesbian, queer, old, fat, clumsy, handicapped, agendered, disproportionately gendered, and black characters, not only for comedic device, but also as a reflection of the women behind those characters. Clowning is a platform of visibility for differences, no matter what they may be, and a means of rendering their intersectional struggle. In her show, Branca de neve politicamente correta, ${ }^{21}$ Diana Bolaño revisits Snow White's tale, raising the gender and race issues enshrined within it. Darina Robles Pérez rewrites in $A$ criaçaó do mundo, ${ }^{22}$ her vision of the world's origin through an indigenous perspective. These reappropriations of history and the stories that compose the cultural foundations of societies - which Maria Brigida de Miranda calls "Herstory" in a game of semantic opposition to "History" Miranda (2017: 4) - remind us how women have been ignored, rebuffed and disenfranchised.

The wide-ranging areas of study of the academics present at the festival, including big clownes, clownes with kinky or frizzy hair, and black clownes reinforced the need to take the diversity of feminist struggle into account, above all those struggles that have long been made invisible. Racism, ageism, ableism, heteronormativity, and fatphobia, are all fields of action that feminism must consider in order to be effective today. In her show/conference Muros e grades saõ invenções humanas, ${ }^{23}$ Ariadne Antico questions the notion of ableism through her amused glance at disability. Concerning ableism, there is no option other than to consider its serious cultural, social and material consequences. The stereotypes and prejudices resulting from it, encourage discrimination against people with disabilities in all social spheres: employment, ed-

21 "Politically correct Snow White"

22 "The world's creation"

23 "Walls and fences are human inventions" 
ucation, sexuality, etc., generating various forms of violence and stigmatization that lead to the perception of life with disabilities as "catastrophic, unhappy, sad, abominable, i.e. a reality that would ruin the quality of life of the person, their relatives and society" Bérard, Zanin (2014: 53).

Considering that discrimination intersectionally takes into account that a woman with a disability also suffers from sexist and heteronormative problems, leading her to be either desexualized or over-sexualized, even fetishized, as is the case for big women - Bérard, Zanin (2014: 57). Through the festival's workshops and performances, women questioned the ownership of their bodies and their right to shape them. If society allows itself to endorse elective medical interventions as intense as breast enlargement, why should women not have the right to own a body with big proportions as well, or those that contradict the social norms of beauty? Putting these interrogations into performance, the clownes in some instances followed or underlined social rules via parody and rebellion, and in others created disonance between sex and gender on their own terms.

To understand the notion of intersectionality as it applies to feminist struggles and to all women, Iris Marion Young prompts us to think of the category of "women" as being outside the essentialist and radical feminist definitions. To do this, she utilizes the Sartrean notion of "seriality" to think of women as a social group, or "series" whose members do not necessarily share the same attributes. More fully: the notion of "women" in this context refers to a series of individuals who, voluntarily or not, passively and interchangeably share political activities with a common objective. Young's illustrative example of a series, people waiting for a bus together, leads us to consider that in this context "no woman can avoid gender markings, but the way gender marks her life is her own" Young Iris Marion (2008: 73) ${ }^{24}$. An archetypical "woman" then, does not exist - no more than does an oppression common to all women - but rather a diversity of women with specific forms of oppression linked to converging struggles.

Even if this complexity and the system surrounding it allow for no easy solutions, clownes have found, through their artistic expression, ways to make visible the marginalizations, current realities and intersectional issues of women in their diversity.

The acts of emancipation and social reform, regardless of how artistic they might be, must pass through a preliminary recognition and take on a new awareness of those same oppressions they seek to subvert. When closely observed, alienation at the hands of social codes is often so imbedded that it remains difficult for each individual to avoid neglecting certain details, which can lead only to the reproduction of schemas. A beginning then, must hold in mind all possible social conditioning and cross it with the interplay of power and class, as well as an awareness of minority groups and the discriminations that concern them. Intersectionality and the plurality of struggles are initial phases of a change now underway and are evidence of the exchange happening between territory as a social space and the collective as a grouping of individuals around a singular objective. It remains then to be asked how clownes in the context of the festival, through their theatrical and artistic language, have unveiled these inequities. What political commentary have they communicated through their performances, and by what means?

24 "Érudit", article de Young Iris Marion. Le genre, structure sérielle : penser les femmes comme un groupe social, Gender as Seriality, https://www.erudit.org/fr/revues/rf/2007-v20-n2-rf2109/017604ar/, accessed April 1 st 2019. 


\section{POLITICS IN THE BODY AND LANGUAGE OF THE CLOWNING ARTFORM}

If the political environment framing clownes and the festival now appears more clearly, then we should turn to the political or politicized statements utilized in the festival's performances. Beyond a given state of affairs brought about by the context, the festival was an opportunity for clownes to take a real platform of visibility and to be heard. Clownes, as women within the Brazilian political system, find themselves facing salient social issues which they clearly denounced in their artistic performances.

Firstly, the matters of everyday life and personal intimacy that were mobilized on the festival's stage will be related to the notion of politics, even if, and especially, because they do not seem immediately affiliated. Secondly, political and artistic statements - especially those related to the concurrent elections - or rather statements thus politicized - will be studied. Finally, language, as a condition that reflects both the social and political system, will be discussed and studied in relation to the attempts at redefinition and reform that clownes are making within the social landscape.

\section{Personal intimacy and everyday life: matters eminently political}

The subject matter of the festival's performances are strongly rooted in everyday life, especially that of women. At first glance, these themes by no means carry the connotation of political statements. Yet the norms of daily social life, by relegating women to minor positions or roles that are often defined in the domestic or private sphere, are eminently political.

If the problems of women and clownes are political, then how they speak of those problems and how they experience them - that is to say personally and often through their bodies is also a matter of politics. A clowne fighting against fatphobia or elective surgery might use the gag-esque image of catching and throwing the fat from her stomach or might, by dancing ballet, evidence that her breasts move enormously. While discrimination is experienced through the clowne's lives and bodies, it is also through their bodies that discrimination is denounced and undermined. Clowning, comedy, and laughter are useful tools for giving expression to that state of repression and domination, and also for deconstructing and restructuring new ways of thinking. By speaking from their point of view, clownes speak universally and reach an audience beyond those present at their performance, speaking directly to a system that comprises us all. The art of clowning manages to create, thanks to laughter, connections and common ground through the caricature of failure, or of the person who fails. A clowne character has a way of taking root in, and sprouting from, the person who embodies her. Clowning allows artists to use their own emotions, personal stories and events as the source material. Clara Lopez, for example, was harassed by a man who tried to kiss her during a street performance. For the next few months, she was unable to perform until she started over by directly integrating the issue into her show. Similarly, clowning has helped Tefa Polidoro ${ }^{25}$ to collaborate with her flaws, enabling her to leave her home and go outside (essential for a street performer). As for Fran Marinho, ${ }^{26}$ clowning allowed her to escape poverty and childhood violence; for her the street was the best way to learn because "if you aren't good, then you starve."

25 Comments made during her workshop A grota que me pariu on 27 September 2018.

26 Comments made during her workshop $A$ melhor historia e aquela que contamos sobre nos mesmas on 27

September 2018. 
As Judith Butler reminds us, "the body exists, but it is the product of an incorporated social history" Butler (2005: 14), meaning that while discrimination runs through it, so does resistance of all kinds. This resistance is clearly visible in the context of artistic practice. If discriminations are made invisible by their integration into the social system, then everyday life and the body are where they find expression. In addition, the public space - controlled by men - redirects and confines feminist struggle to the private sphere. That is what the aphorism "the personal is political" refers to, Lima Campos (2017:39). If the majority of the subjects explored by clownes make reference to the body and daily life, it is because women are constantly relegated to these spheres, the social spaces where feminist struggles most blatently appear and are played out.

Keeping in mind the idea of seriality evoked earlier, while jettisoning the idea of "woman" in the singular to make room for the concept of women in their diversity, it must be observed then, that neither feminine humor nor feminine interests or themes can be said to exist. Feminist subjects can be defined as such only because they represent experienced oppression, whether that experience be voluntary or not. To take up the image used to illustrate the idea of a seriality (individuals waiting for a bus), the facts are that the women's bus has been painted pink, and that this bus line passes less frequently than the others, all of which is orchestrated by the bus company. Therefore, if women on that line talk of buses, they will consider, consciously or unconsciously, their color or schedules. During an informal outing with female clownes, one of them wore a $O$ meu corpo e politico ${ }^{27}$ t-shirt. Similarly, Romana Melo's performance Querem caferem ${ }^{28}$ unfolded in a kitchen, and Cris Munõz's Perifericos ${ }^{29}$ attacked the question of masturbation head-on and with stripping wit. By approaching the political realm through the poiesis of personal and intimate themes, social norms are thus redefined, passing from the shadows where they were played out into the public and political space to which they belong. The festival's performances brought themes such as marriage, pregnancy, cooking, striptease, masturbation, and superwomen to this stage.

The clownes were able to reflect feminist issues through intimate and private themes, because these are spaces to which they are relegated as women. In addition to these ordinary themes, what of politics was expressed as such, particularly in relation to the elections?

\section{Political engagement and political speech "strictly speaking"}

In addition to raising questions of sexism in everyday life, or simply making their struggles as women visible, the clownes took advantage of the first round of elections by politicizing their festival performances.

Beyond the indirect political positions adopted, the clowns made direct political actions and comments through their shows or acts. For example, Tefa Polidoro's makes title and eponyme of the feminist formula "not one less," which was coined in 2015. Her show discusses delicate current affairs and issues through the character of a tramp buffoon. Due to the political changes that were underway at the time of the festival - including the imminent election of Jair Bolzonaro and the resulting outcry within the LGBTQIA+ and feminist communities - all the

27 "My body is political"

28 "Want a coffee?"

29 "Peripheral" 
clownes present at the festival took a stand, whether by carrying signs or stickers on their person or through political chants and phrases used during their shows, in favour of the "\#elenaõ" opposition. Similarly, Ana Borges, festival organizer and clowne, pointed out that the Queer cabaret took place at the same time as the women's march in Rio, in line with the festival's political engagement. One must also hope that if, "organized movements and protests related to feminist and gender causes have gained more visibility in Brazil in the last decade" Miranda (2017: 1), current political events will not then prevent this dynamic from continuing, nor slow the ideas of inclusivity from taking root in the movements of feminism and clowning.

In her workshop, Tefa Polidoro explained that by purposefully working with mistakes and failures, the art of clowning questions the productivist perspectives of capitalism. In the same vein, she suggested that her students save their trash in a bag for a week and bring it with them to the workshop, thereby interrogating the logic of consumption that accompanies capitalism, transforming a political thought, via the art of clowning, into political action.

The political dimension is omnipresent within Brazilian clowning and more broadly than that of Latin America. Clowne Darina Robles Perez, who attended the Gaulier school and has a background in art history, now works with Clowns Without Borders to accompany (and, if possible, to alleviate the pain of) migrants who suffer countless acts of violence (kidnapping, serious injuries, extreme poverty). During a duo exercise in her workshop, Tefa Polidoro was obliged to point out the political meaning woven into the cloth of the participants' artistic choices. For example, if the duo is made up of a person with dark skin and a person with light skin then examples such as portraying an injustice, deploying techniques of comic humiliation or veneration, or reprising the white clown/Augustus techniques, would not go without underlying racial meanings. In the same vein, in imitating an animal, the workshop asked the participants to question the animal's gender: to choose lion or lioness to represent ferocity and to ask why? To give an emblematic example, if in Brazil red noses are worn with no hesitation, in France, a clowne must ask herself whether or not to use one in her career. This is because the political dimension prevails - in Brazil the symbol is marshaled to re-vindicate the status of women and their right to work as clownes, while in France, the symbol is questioned as part of an effort to legitimize an art form in trouble.

Politics, in its widest as well as its many literal and figurative accepted definitions, is omnipresent in Brazil, at the festival Esse Monte de Mulher Palhaça, for the women attending and thus, for the clownes. There is, however, a forgotten, discrete, aspect of discrimination's violence that herein remains unexplored: language. How do clownes respond to the terminologies defining them? What are the linguistic counter-proposals made by the clownes?

\section{CONCLUDING REMARKS: A NOTE ON TERMINOLOGY}

Language is a labeler, an indicator, and a conceiver of social reality. Our question is how language interacts with clownes, what contours it lays out for them, and how they respond.

Words, like stereotypes, are necessary for the structure and classification of each and every one of our social and individual realities. At the same time words and their meaning, when spoken, freeze. Monique Wittig argues that "even abstract and philosophical catego- 
ries act upon reality as a social reality. Language projects beams of reality on the social body" Wittig (2013: 117). Language is used to understand, to generate a necessary order and to define, but as it does so, it freezes the definition for a period of time that often outlives the reality reflected. When an official change is made to a dictionary, it is often a sign that common meaning changed long ago. This delay is probably one of the reasons for the perpetuation of outmoded structures and thought. Amin Maalouf emphasizes that "it[...] seems important for each of us to be aware that his words are not innocent, and that they contribute to the perpetuation of prejudices that have proven themselves, throughout history, to be perverse and murderous" Maalouf (2011: 29).

In a way, it is not wrong to think that language, in addition to freezing reality, can influence it. The term "palhaço/a," referring to traditional circus clown.e.s, was put aside in the 1980's with the arrival of the "nouveaux.elles" clown.e.s in Europe, Cézard (2014), which had a massive influence in Latin America, especially in Brazil. While in France the word "clown" was not discussed in terms of its sexism, in Brazil the word "clown" was quickly challenged at the time because it opposed the term "palhaço/a", which had more inherent flexibility. Indeed, this specific term allows itself to be gendered by ending in "o" or "a" or to be ungendered through the use of the derived "palhaceria," and became common use in popular language (its origin) and scientific language (when feminist) 30 to designate all clown.e.s. be they "traditionel.les" or "nouveaux.elles" 31 .

The lexical and therefore semantic variations of the term align it with the inclusivity necessary to the feminist and clowning movements in Brazil, as well as with the characteristics of diversity and change inherent in society. It is, therefore, with a purposeful re-appropriation that clownes take up the term "palhaça", referring to the existence of female clowns on the same professional level and title as men. The use of words is both a reflection and an action. It is a reflection in that it shows the evolution of mentalities and history; it is an action in that a linguistic choice constantly interjects with social reality, allowing itself to be defined by that reality and also shaping it.

It is important to conceptualize statements in a broad socio-economic-historical-political perspective, but also from a personal point of view. ${ }^{32}$ In light of these reflections, the limits of the use of gendered terms is emerging, as in the case of "palhaço/a." In effect, underlining and recognizing gender still grants it a certain power. It means acknowledging that gender remains intractable, and that no proposal can successfully abolish or replace it. For example, while the declaration of color or race on civil status/identification has been considered a form of discrimination since the end of slavery, this is not the case for sex declaration, which "not even women have dreamed of abolishing" Wittig (2013: 44).

To completely reform the system and put an end to the sexism that prevails within it, there is no alternative but to move away from language that retains a trace of gender, treating

30 It seems that there is some resistance from a male and heterosexual class, despite their informed state concerning the current tranformations and debates taking place relative to clownes.

31 I have unfortunately been unable to find an official source of information for the moment regarding semantic modification and terminology. According to Ana Borges, the term "Palhacaria" arrived in 2010.

32 Five years ago, my statements on clowning reflected my perspectives but held gaps concerning the study of gender, the feminisit movement, and of clowning around the world. In effect, even if I studied the "new clowns," as well as the sexist perspective, I failed to apply the appropriate inclusive changes in my own language. 
it as an indelible mark of political injustice, and turn to find a "linguagem nova" Rago (1998: 10). The study of the nicknames in Claude Levi-Strauss's work shows an interesting direction for alternatives coming from the world of clowning. Like a clowne's costume, which is nothing if not a joke made of cloth, a nickname, or monaker which is a joke made of language. They allow clownes to find an artistic solution to social labeling by highlighting a deviation from the norm. For example, "in Minot [France], the nickname abolishes social differences and, unlike a surname or first name, does not define a social position, it marks rather a place within the community" Levi-Strauss (1983: 271).

We can also look at "gromelot," the clowning language, a method of audible communication that, strictly speaking, carries no meaning except when related to gestures and intonation. Developed on the basis of sound, onomatopoeia and fragments of words, Cézard (2014: 177), it would have, according to Tristan Rémy, been invented in the face of "féeriques"or military pantomimes becoming prohibited in circuses, Rémi (1962:12). This language makes it possible to re-model reality, or at least to call it into question by offering it a space for parody.

The different modalities of the notion of politics thus crossed the world of clowning and clownes during Esse Monte de Mulher Palhaça, be it through the use of language, political statements, the themes addressed, the performances, or the location of the festival, which was itself a work of the feminist movement.

To reform current systems of thought, clown.e.s take on the task of directly denouncing abuses of power, especially capitalist acts, and returning the right of freedom of speech to the minorities that they themselves represent. Clownes' modification of language renders it capable of translating their realities and experience, allowing the language itself tools for its emancipation from the associated systems. In the same way the body becomes activist through its presentation in the art of clowning as a political reality. The body may be considered in fact as the smallest political territory within the geo-political space it belongs to.

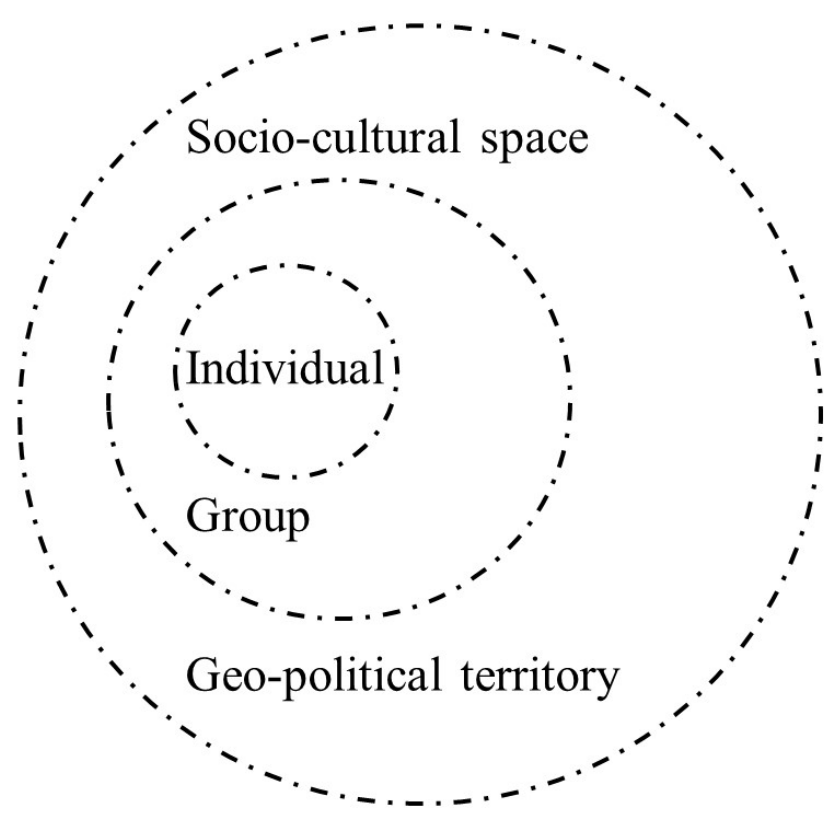

Within this schema, it appears that the private sphere, whether political bodies or individuals, interact constantly with the collective to which they belong, in this case the world of 
clown.e.s, which itself takes form within and interacts with a socio-cultural space that, in turn, acts on and is a part of the notion of geo-political territory.

To upend the system as it has been described, namely andocentric, phallocentric, capitalist, monogamous, and heteronormative, and to step outside of it, the discrimininations that it carries must be made visible, including through the art of clowning. Brazilian clownes adhere today and are more significant than ever to the interplay of politics. If "feminism proposes a new relationship between theory and practice" Rago (1998: 11), then clownes' intrinsically political nature delivers a powerful rendering - especially when confronted with a repressive and authoritarian political context - of thought into theory and practice into activism. Huguette Dagenais points out that leaving aside pop feminism, Miranda (2017: 2) and perhaps cultural feminism, the long awaited "mainstream" of feminist publications, and feminism itself, has not materialized, Dagenais (1997). This large-scale lack of visibility, which easily applies itself to clownes, indicates that women and feminist thinking are still not seen as meriting more attention.

The study of the festival Esse Monte de Mulher Palhaca, provides an example of a growing phenomina in Latin America and Brazil, giving evidence of how the practice of clowning allows these women to take their speech and render it political and therefore feminist, and to engage with the struggle against injustice and social invisibility. Activism is intrinsic in the clowne's struggle. Beginning from the conditions of their existence and survival of the statements and performances they create, tangible and effective political actions are made possible. Revolutionary counter-proposals and strategies may be realized through this artistic practice, because it knows nothing but irreverence. We must hope the practice bears a great influence upon reality and an extremity of thought, of which herein we have only grazed the surface.

\section{BIBLIOGRAPHY}

Bastien Charlebois. 2014. "Femmes intersexes : sujet politique extrême du féminisme". Pp. 237-255 in Femmes extrêmes - Recherches Féministes. Université Laval : GREMF, vol²7, $\mathrm{n}^{\circ} 1$.

Becker Howard S. 2009. Comment parler de la société. Paris : La Découverte.

Becker Howard S. 1988. Les Mondes de l'art. Paris : Flammarion.

Bérard Sylvie, Zanin Andréa (Textes réunis par). 2014. Femmes extrêmes - Recherches Féministes. Université Laval : GREMF, vol ${ }^{\circ} 27, \mathrm{n}^{\circ} 1$.

Bertaux Daniel. 1977. Destins personnels et structure de classe. Paris : Puf, politiques.

Bertaux Daniel. 1997. Les récits de vie. Paris : Nathan, coll. «128».

Bourdieu Pierre. 2002. La Domination masculine. Paris : Seuil.

Butler Judith. 2005. Trouble dans le genre - Pour un féminisme de la subversion. Paris : Édition La Découverte.

Castro Alice Viveiro de. 2005. O Elogio da Bobagem : Palhaços no Brasil e no Mundo. Familia Bastos.

Cézard Delphine. 2014. Les "Nouveaux" clowns : approche sociologique de l'identité, de la profession et de l'art du clown aujourd'hui. Paris : L'Harmattan. 
Dagenais Huguette. 1997. "L'institutionnalisation des études féministes à l'université du Québec”. Pp. 35-58. Politique et recherches féministes, regards croisés, n6. Available at $<$ https://journals.openedition.org/cedref/660>

Detrez Christine et Simon Anne. 2006. À leurs corps défendant - Les Femmes à l'épreuve du nouvel ordre moral. Paris : Édition du Seuil.

Figueiredo Ângela. 2018. "Perspectiva e contribuçoes das organizaçoes de mulheres negras e feministas negras contra o racismo e o sexismo na sociedade brasileila”. Pp. 1080-1099. Direito e Praxi. Rio de Janeiro, vol ${ }^{\circ} 9, \mathrm{n}^{\circ} 2$.

Garfinkel Harold. 2007. Recherches en ethnométhodologie. Paris : Presses Universitaires de France. Hooks Bell. 2015. Ne suis-je pas une femme? Femmes noires et féminisme. Paris : Éditions Cambourakis.

Kaufmann Jean-Claude. 2008. Quand Je est un autre - Pourquoi et comment ça change en nous. Paris : Armand Colin.

Lahire Bernard. 2004. La culture des individus - Dissonances culturelles et distinctions de soi. Paris : La Découverte.

Lamoureux Ève, St-Gelais Thérèse (Textes réunis par). 2014. Où en sommes-nous avec le féminisme en art? - Recherches Féministes. Université Laval : GREMF, vol $27, n^{\circ} 2$.

Lamoureux Diane, Dupuis-Déri Francis. 2015. Les antiféminismes, analyse d'un discours réactionnaire. Montréal : les éditions du remue-ménage.

Le Breton David. 1990. Anthropologie du corps et modernité. Paris : Presses Universitaires de France.

Le Coq Sophie. 2004. Le travail artistique : effritement du modèle de l'artiste créateur. Paris : l'Harmattan. Available at <https://www.cairn.info/revue-sociologie-de-1-art-2004-3-page-111. html>

Leveratto Jean-Marc. 2000. La mesure de l'art, sociologie de la qualité artistique. Paris : La Dispute. Levi-Strauss Claude. 1983. L'identité. Paris : Presses Universitaires de France.

Lima Campos (de) Mariana. 2017. "Feminismo e movimentos de mulheres no contexto brasileiro : a constitutição de indentidades coletivas e a busca de incidência nas politicas publicas". Pp. 35-54 in Revistas Sociais E bumanas vol 30.

Maalouf Amin. 2001. Les Identités meurtrières. Paris : Le livre de poche.

Miranda de Maria Brigida. 2017. Teatro feministas na ilha das bruxas : memorias «herstory» de praticas teatrais feministas em florianopolis. Florianopolis : Seminario Internacional Fazendo Gênero 11 \& 13 Women's Worlds Congress.

Pillar Grossi Miriam. 2005. "Novas/velhas violências contra a mulher no Brasil”. Pp. 473-483 in Estudos Feministas, Florianopolis, n 94.

Rago Margareth. 1998. "Epistemologia Feminista, Genêro e Historia”. In : Pedro, Joana : Grossi, Miriam (orgs.). Florianopolis : Éditions Mulheres.

Simoes Minella Luzinette, Pillar Grossi Miriam. 2003. "Publicações feministas brasileiras : compartilhando experiências". Pp. 217-223 in Estudos Feministas. Florianopolis, 11.

Thery Irène. 2007. La Distinction de sexe - Une nouvelle approche de l'égalité. Paris : Odile Jacob. Tristan Rémy. 1962. Entrées clownesques. Paris : L'Arche.

Wittig Monique. 2013. La Pensée straight. Paris : Éditions Amsterdam 